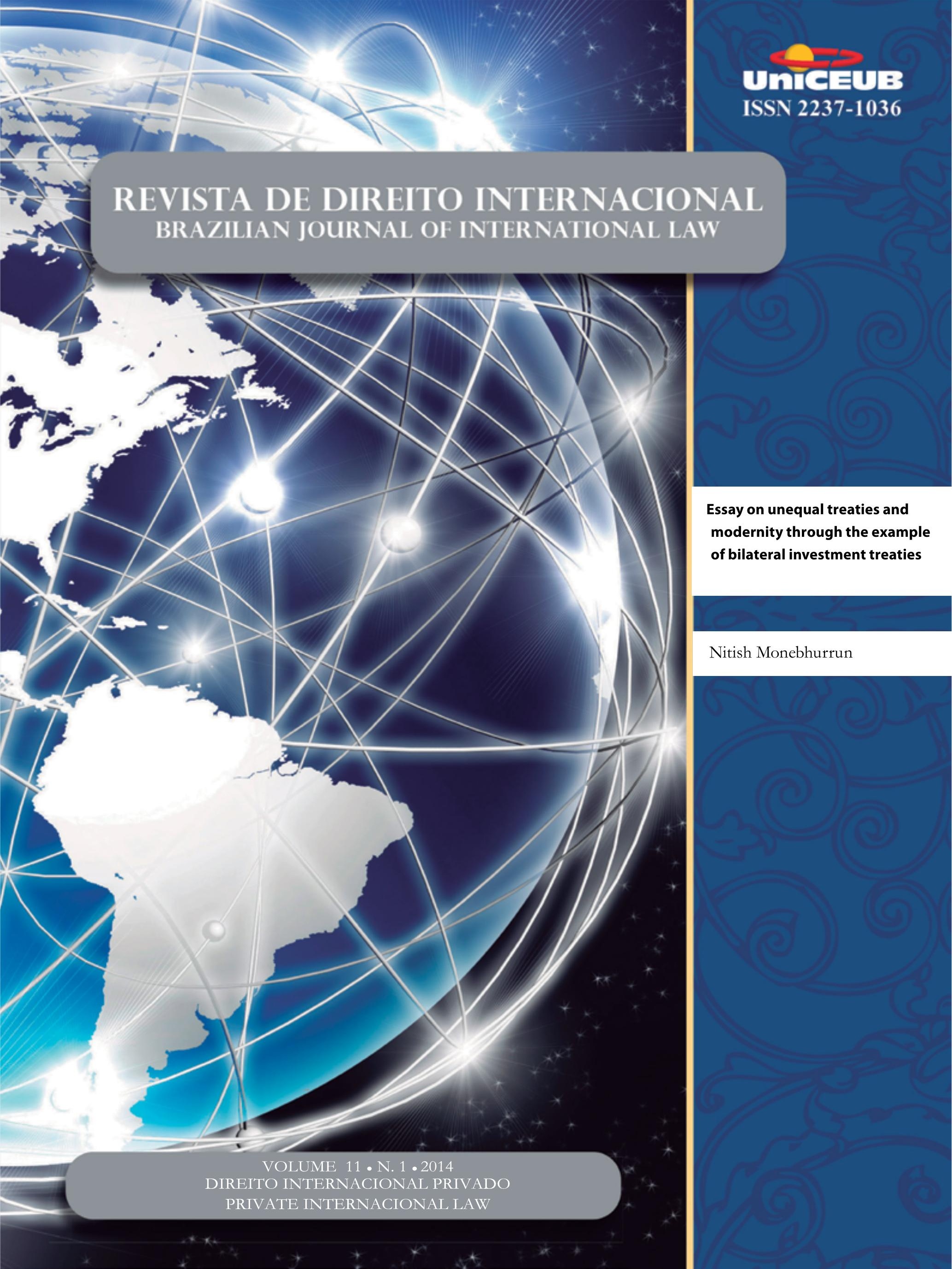




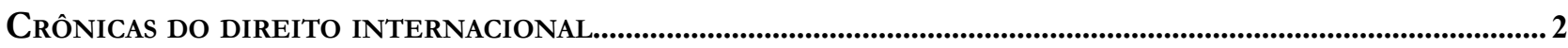

Nitish Monebhurrun

Alice Rocha da Silva

Julia Motte-Baumvol

Rafael Freitas de Oliveira

Roberta Greco

CRÔNICAS DO DIREITO INTERNACIONAL DOS INVESTIMENTOS .11

Nitish Monebhurrun

Reconhecimento E ExecuÇão de Sentenças Estrangeiras: anÁlise do projeto Em andamento na Conferência da Haia de Direito Internacional Privado

Nadia de Araujo

Fabrício Bertini Pasquot Polido

Os CASAMENTOS E AS PARCERIAS ENTRE PESSOAS DO MESMO SEXO NO DIREITO INTERNACIONAL PRIVAdO BRASILEIRO: ASPECTOS TRANSNACIONAIS DAS FAMÍLIAS CONTEMPORÂNEAS.

Bruno Rodrigues de Almeida

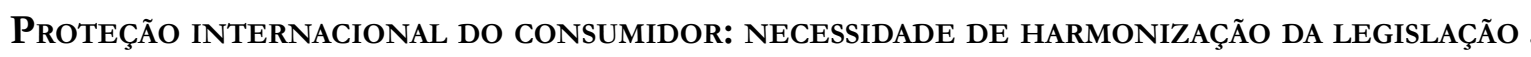
54

Héctor Valverde Santana

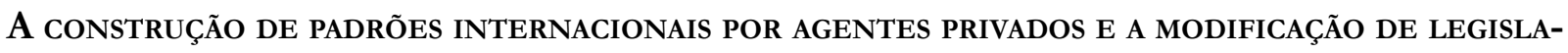
Ção NACIONAL: ALTERAÇÃo do PADRÃo DE CONTABILIDADE PARA EMPRESÁRIOS NO BRASIL.

Cleíse Nascimento Martins Costa

THE DEBATE ON COMPANIES' LIABILITY FOR INTERNATIONAL ENVIRONMENTAL DAMAGES: A COMPARISON BETWEEN THE JURISDiCTIONAL RULES OF THE EUROPEAN UNION AND THE UNITED STATES

Carina Costa de Oliveira

DesenVOlVIMENTO E APLICAÇÃo DA TEORIA dos VíNCUlOS MAIS ESTREITOS NO DIREITO INTERNACIONAL PRIVADO: POR UMA REDISCUSSÃO DO MÉTODO DE SOLUÇÃO DO CONFLITO DE LEIS 101

Jamile Bergamaschine Mata Diz

Rodrigo Vaslin Diniz

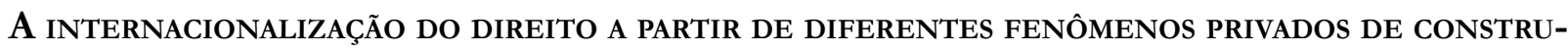
ÇÃO NORMATIVA 117

Fernando Lopes Ferraz Elias 
Leilane Serratine Grubba

Human TRAFFicking: IDENTIFYING FORCED LABOR IN MULTINATIONAL CORPORATIONS \& THE IMPLICATIONS OF LIABILITY

Tara M. Parente

Aplicação dos princípios UNIDROIT no Plano Brasil maior: o SUPRIMENTO de UMA lacuna NA POLÍTICA BRASILEIRA DE DESENVOLVIMENTO ECONÔMICO

Guilherme Freire de Melo Barros

Marcelle Franco Espíndola Barros

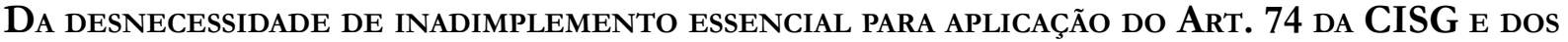
DANOS EFETIVAMENTE RECUPERÁVEIS

Renata Caroline Kroska

ESSAY ON UNEQUAL TREATIES AND MODERNITY THROUGH THE EXAMPLE OF BILATERAL INVESTMENT TREATIES

Nitish Monebhurrun

CONCEITOS DE RELAÇÕES INTERNACIONAIS E TEORIA DO DIREITO DIANTE DOS EFEITOS PLURALISTAS DA GLOBALIZAÇÃO: GOVERNANÇA GLOBAL, REGIMES JURÍDICOS, DIREITO REFLEXIVO, PLURALISMO JURÍDICO,

CORREGULAÇÃO E AUTORREGULAÇÃO . 216

Gabriela Garcia Batista Lima

\section{Outros Temas}

CONVENÇão SOBRE OS DIREITOS DAS PESSOAS COM DEFICIÊNCIA: COMO "INVISÍVEIS" CONQUISTARAM SEU ESPAÇO .230

Luana da Silva Vittorati

Matheus de Carvalho Hernandez 


\title{
ESSAY ON UNEQUAL TREATIES AND MODERNITY THROUGH THE EXAMPLE OF BILATERAL INVESTMENT TREATIES*
}

\author{
Nitish Monebhurrun**
}

\begin{abstract}
Unequal treaties and its theory have long been inhumed by the evolution of modern international law and reciprocity has become the principle in the quest of balancing rights and obligations of States party to a bilateral agreement. Despite this accepted configuration, a particular type of now expanding agreement the bilateral investment treaty -, has sometimes been criticised in reason of the disequilibrium which mark its substance. Some of these agreements may, at first sight, raise the equality conundrum; others have been denounced for similar reasons. By excavating the buried and perhaps forgotten theory of unequal treaties, this article explains the normality of the disequilibrium and inequality characterising some international agreements and legal practices, and does this through the lenses of bilateral investment treaties used as an illustration.
\end{abstract}

Keywords: Unequal treaties. Theory. Bilateralinvestment treaties. Disequilibrium.

\section{Resumo}

Tratados desiguais junto com a sua teoria têm sido enterrados e esquecidos pela evolução do direito internacional moderno, e a reciprocidade tornou-se o princípio, com o objetivo de encontrar um equilíbrio entre direitos e obrigações dos Estados assinatórios de um tratado bilateral. Embora a existência dessa configuração, um novo tipo de tratado - os tratados bilaterais sobre a proteção dos investimentos -, tem sido criticado em razão da sua falta de desequilíbrio. Alguns destes justamente apontam a problemática da igualdade; outros foram denunciados pela mesma razão. Ao escavar a teoria dos tratados desiguais, este artigo afirma a normalidae do desequilíbrio e da disigualdade que caraterizam alguns acordos internacionais e a prática dela decorrente; assim sendo, utiliza-se o exemplo dos tratados bilaterais sobre os investimentos a título de exemplo.

Palavras chaves: Tratados desiguais. Teoria. Tratados bilaterais sobre os investimentos. Desequilíbrio.

\section{Introduction}

It would be a truism to note the unequal aspects of international relations. States have various levels of economic power which determine their political influence: the latter marks their position on the international scene. The law, as for it, aims at polishing these differences by creating a legal equality between States. This is, for example, what is provided for by the United Nations Charter's preamble and by its articles $1(2), 2(1)$ and $55^{1}$ on sovereign equality. The principle of equality has a reversed logic: it erases in theory the factual inequality which

\footnotetext{
** Doctor in International Law (School
of Law of Sorbonne, Paris) and Associate
Professor (University Centre of Brasilia).
E-mail: nitish.monebhurrun@gmail.com

** Doctor in International Law (School
of Law of Sorbonne, Paris) and Associate
Professor (University Centre of Brasilia).
E-mail: nitish.monebhurrun@gmail.com

** Doctor in International Law (School
of Law of Sorbonne, Paris) and Associate
Professor (University Centre of Brasilia).
E-mail: nitish.monebhurrun@gmail.com

** Doctor in International Law (School
of Law of Sorbonne, Paris) and Associate
Professor (University Centre of Brasilia).
E-mail: nitish.monebhurrun@gmail.com

* Recebido em: 12.04.2014 Aprovado em: 20.05.2014
}

$$
\text { of equality has a reversed logic: it erases in theory the factual inequality which }
$$

1 See: The United Nations Charter, available on: http://www.un.org/fr/documents/charter/ 
practically exists ${ }^{2}$. It is dressed with a psychological peel as it enables to tolerate and support the other types of inequality ${ }^{3}$. Equality between States means similar rights, similar duties and similar treatment ${ }^{4}$. States are equal legal subjects taken for granted that international law grants them with a similar level of protection while crediting them with the same duties ${ }^{5}$. For some authors this "forensic equality" must not even be proved: it is obvious $^{6}$. Despite the inequality of States in terms of size, of population, of power or wealth, they remain equal international legal entities? This being said, there is often a direct relationship between States' power and the process of creation of international law - and of its enforcement afterwards ${ }^{8}$. Consequently, and as asserted by Kelsen, this legal equality is merely theoretical. It constitutes the expression of the principle of a legal theory and not - intrinsically -, of the substance of law. And, it is the latter which is normally most relevant to interpret the principle of States' equality. Equality of States is construed as implying equality of their rights, and it cannot be supported that States always have the same rights and the same obligations: this would obviously be contrary to the legal reality?

Still, under this configuration, modern international agreements are not tantamount to unequal treaties. Unequal treaties are those which are imposed upon States by other States using military, political or economical force, and which are not grounded on the

2 SCHINDLER Dietrich. Contribution à l'étude des facteurs sociologiques et psychologiques du droit international. R.C.A.D.I., ano 4 , v. 46, p. 261.

3 Ibid., p.263.

4 SCOTT, James Brown. Le principe de l'égalité juridique dans les rapports internationaux. R.C.A.D.I., ano 4, v. 42, p. 477.

5 PREUSS, Ulrich K. Equality of States-Its Meaning in a Constitutionalized Global Order. Chicago Journal of International Law, v. 9, p. 18, 2008-2009; VAN, Wynen thomas Ann. THOMAS JUNIOR, A. J. Equality of States in International Law: Fact or Fiction? Virginia Law Review, v. 37, n. 6, p. 801-802, oct. 1951

6 MCNAIR, Arnold D. Equality in International Law. Michigan Law Review, v. 36, n. 2, p. 136, déc. 1927.

7 OPPENHEIM, Lassa. International Law: a treaties. 3. ed. Londres: Ronald F. Roxburg, 2008. p. 196.

8 SCHINDLER, Dietrich. op. cit., p.262.; VAN, Wynen Thomas Ann, THOMAS JUNIOR, A. J. op. cit., p. 802.

9 KELSEN, Hans. Théorie générale du droit international public: problèmes choisis. R.C.A.D.I., ano 4, v. 42, p. 190, 1932; see also: GILBERT, Guillaume. Droits et devoirs des nations: la théorie classique des droits fondamentaux des Etats. R.C.A.D.I., ano 5, v. 10, p. 593-597, 1925; VERDROSS, Alfred. Règles générales du droit international de la paix. R.C.A.D.I., ano 5, v. 30, p. 415, 1929; SCHINDLER, Dietrich. op. cit., p. 262. principle of reciprocity; the rights and duties of the parties are, therein, not reciprocal ${ }^{10}$. The old, longburied theory of unequal treaties is here mentioned and excavated for the purpose of analysing one specific conundrum - at least, sometimes considered as such by some - , of international investment law: the socalled imbalanced nature of bilateral investment treaties. Bilateral treaties are signed between States to offer reciprocal protection to their investors. Some States especially Latin American ones ${ }^{11}$ - have been criticising the general system of international investment law and their flanked bilateral investment agreements for being flawed with an inherent disequilibrium. The system is often considered as imbalanced in favour of foreign investors. Bilateral investment treaties which are signed between States to protect and to promote international investments provide an arsenal of rights to foreign investors without providing for equivalent obligations. An investor can claim rights by invoking the provisions of an investment agreement but he cannot be held liable for any obligation under the same treaty. Conversely, States have an obligation to protect foreign investors as per the investment-related agreements they have ratified, but they cannot expect any reciprocal obligation from them. In a nutshell therefore, investors have mostly rights and no obligations towards States which have, on their side, mostly obligations but no equivalent rights in their relation with investors. For part of the doctrine, international investment law is a monster of power aiming only at the protection of investors and their investments, ignoring in this process the other interests implied by presence of other actors $^{12}$. Politically, the President of Ecuador, Raphael Correa has, for example, explained the necessity of

10 DETTER, Ingrid. The Problem of Unequal Treaties. International and Comparative Law Quarterly, v. 15, p. 1073, 1966; GROTIUS, Hugo. Le droit de la guerre et de la paix. Trad. Jean Barbeyrac. Amsterdam: Pierre de Coup. p. 546, t. 1. cap. 15; PETERS, Anne. Unequal treaties: the max planck encyclopedia of public international law. Oxford University Press, 2011. Available on: <www.mpepil.com>. p.8.

11 GAILLARD, Emmanuel. Anti-Arbitration Trends in Latin America. New York Law Journal, v. 239, n. 108, 2008; GARCIABOLIVAR, Omar E. The surge of investment disputes: Latin America testing the international law of foreign investments. In: GENERAL CONFERENCE OF THE ASIAN SOCIETY OF INTERNATIONAL LAW, 2., 2009, Tokyo. Proceeding... Tokyo. 2009. p. 4-6; FACH, Katia Gomez. Latin America and ICSID: David versus Goliath. Law and Business Review of the Americas, v. 17, p. 195-230, 2011. 12 SORNARAJAH, Muthucumaraswamy. The Settlement of Foreign Investment Disputes. The Hague: Kluwer Law International, 2000. p. 9. 
denouncing the Washington Convention ${ }^{13}$ instituting the International Centre for the Settlement of Investment Disputes by affirming with sheer virulence that this initiative implied freedom of States from ICSID which symbolises colonialism, enslavement by multinational companies, by Washington and by the World Bank ${ }^{14}$. He also - wrongly - affirmed that developing countries always lost against private companies in international arbitration proceedings ${ }^{15}$. There is the idea that States, namely developing ones, are the pariahs with no real rights in an imbalanced international investment law system ${ }^{16}$. They have no legal title to claim and therefore no interest to start any action before an arbitral tribunal ${ }^{17}$.

Initially, such investment agreements were derived from treaty models of developed States which proposed them to their partners - the developing States -, and they were signed without any thorough negotiation process $^{18}$. These were often agreements between newly decolonised States and ancient colonial States. Many of these agreements are still in force and there are very few treaty models from developing States. There is an ongoing movement in Latin America with, for example, the Colombian bilateral investment treaty model of $2007^{19}$, but the process is far from being completed as confirmed, for example, by the American refusal in 2006 to consider a Bolivian proposition on an equitable

13 The Convention is available on: http://icsid.worldbank.org/ ICSID/StaticFiles/basicdoc_en-archive/ICSID_English.pdf

14 See: Investment Treaty News, Jun 2009, p. 3. Available on: $<$ www.investmenttreatynews.org>.

15 FRANCK, Suzanne. Development and outcome of investment treaty arbitration. Harvard International Law Journal, v. 50, n. 2, p. 202, 2009.

16 HELLIO, Hugues. L'Etat, un justiciable de second ordre? A propos des demandes étatiques dans le contentieux arbitral transnational relatif aux investissements étrangers. RGDIP, ano 113, n. 3, p. 598, 2009; See also: Le système actuel est-il déséquilibré en faveur de l'investisseur privé étranger et au détriment de l'Etat d'accueil (Table ronde), In: LEBEN, Charles. (Org.). Le contentieux arbitral transnational relatif à l'investissement. Nouveaux développement. Paris: LGDJ, Anthémis, 2006. p. 185-202; EL BOUDOUHI, Saïda. L'intérêt général et les règles substantielles de protection des investissements. AFDI, p. 542, 2005.

17 HELLIO, op. cit., p. 598.

18 JUILLARD, Patrick. Le système actuel est-il déséquilibré en faveur de l'investisseur privé étranger et au détriment de l'Etat d'accueil? (Table Ronde). In: LEBEN, Charles (Org.). Le contentieux arbitral transnational relatif à l'investissement. Nouveaux Développements. Paris: L.G.D.J., 2006. p.191.

19 The Colombian treaty model is available on: http://italaw. com/documents/inv_model_bit_colombia.pdf trade agreement between the two States ${ }^{20}$. Developing States have a very relative capacity to negotiate with industrialised ones and they cannot easily impose their conditions during negotiations. This is surely one of the reasons why bilateral investment treaties do not normally refer in an extensive mode to the interests of developing countries ${ }^{21}$. However, the question of the political and economical force is not the only reason for this. The agreements between developing States are in turn not always really negotiated, and contain very few provisions valuing their interests. It is often an existing model of a developed State which will be used by a developing State in its economic relationship with other developing States ${ }^{22}$; at least, various agreements between developing States have followed this path. This is sometimes due to a lack of expertise and technical know-know ${ }^{23}$ - and is also perhaps related to a fashion trend whereby each State must have its own constellation of agreements. Exceptions exist. Many bilateral investment treaties of Singapore, for example, are not mere reproductions of existing European treaty models ${ }^{24}$. Standing as an exception in the field, Brazil has, for the moment, not ratified any bilateral investment treaty - without hindering the flows of investments towards its territory ${ }^{25}$.

There is surely a disequilibrium in treaty negotiations but this pertains to the cold reality of international relations which are characterised by their unequal

20 FACH, Katia Gomez. op. cit., p. 216-221; VIS-DUNBAR Damon. Analysis: Latin America's new model bilateral investment treaties. Investment Treaty News, 17 jul. 2008. Available at: <http:// www.iisd.org/itn/2008/07/17/in-depth-latin-america-s-newmodel-bilateral-investment-treaties $/>$.

21 ALEXANDER, Emily. A. Taking Account of Reality: Adopting Contextual Standards for Developing Countries in International Investment Law. Virginia Journal of International Law, v. 48, p. 823-824, 2008.

22 MALIK, Manaz. South-South Bilateral Investment Treaties: the same old story? In: FORUM FOR DEVELOPING COUNTRY INVESTMENT NEGOTIATORS BACKGROUND PAPERS NEW DELHI, 4., 2010. Anais... 2010.In:THEINTERNATIONAL INSTITUTE OF SUSTAINABLE DEVELOPMENT, 2011, p.1-5. Available on: <http://www.iisd.org/pdf/2011/dci_2010_south_ bits.pdf $>$. p. 1-5; VANDEVELDE, Kenneth. J. a brief history of International Investment Agreements. University of California Davis Journal of International Law and Policy, v. 12, p. 170, 2005.

23 MALIK, op. cit., p. 1-5.

24 Ibid.

25 See: WHITSITT, Elizabeth. VIS-DUNBAR, Damon. Investment Arbitration in Brazil: yes or no?. Investment Treaty News, 30 nov. 2008. Available on: <http://www.iisd.org/itn/2008/11/30/ investment-arbitration-in-brazil-yes-or-no/> 
nature. If this has an effect on the creation of law, it does not necessarily means that the law produced is in itself imbalanced. And even if it were, the problem might not be purely legal; it might simply be a moral appreciation without any serious effects on the legal structure. Through the lenses of the theory of unequal treaties which must here be excavated and developed for being an old, nearly fossilised concept (I), it can be affirmed and confirmed that the latter does not apply to investment agreements - despite the latter's appearance (II).

\subsection{Excavating The Theory of Unequal Treaties}

Studying this theory starts by an analysis of the legal status of unequal treaties (A) before understanding the reasons grounding their former existence (B).

\section{(A) The Legal Status of Unequal Treaties}

The inequality characterising an unequal treaty rests on the imbalanced promises which it contains whereby one party is made inferior to the other ${ }^{26}$. The inexistence of reciprocity is here a critical and determining factor ${ }^{27}$ : the inter-State relationship favours one of the parties in an unreasonable manner ${ }^{28}$; the interests of one party are valued, those of the other are ignored ${ }^{29}$. The inequality is substantial and procedural. It is substantial as the obligations of the parties are not symmetrical, and it can be procedural if the treaty has been concluded by the means of force and violence, flawing subsequently one of the parties' consent ${ }^{30}$. Many treaties concluded by European States with indigenous peoples of conquered territories during the colonisation periods between the 16th and the 17 th century have been considered as substantially and procedurally unequal ${ }^{31}$. The most famous unequal treaties are certainly the Chinese ones ${ }^{32}$. More than

26 WANG, Tieya. International law in China: historical and contemporary perspectives. R.C.A.D.I., ano 2, v. 221, p. 334, 1990.

27 PETERS, op. cit., p.8.

28 GROTIUS, op. cit., p. 546.

29 DETTER, op. cit., p. 1073.

30 PETERS, op. cit., p. 2.

31 PETERS, op. cit., p. 3.

32 CRAVEN, Matthew. What happened to unequal treaties? the continuities of informal empire. Nordic Journal of International Law, v. 74, p. 343, 2005; FINKELSTEIN, Jesse. A. An examination of the treaties governing the far-eastern sino-soviet border in light of the a thousand treaties signed by China with eighteen States between 1842 and 1949 have been construed as unequal ${ }^{33}$. Some of these States were, for example, the United-States, the United Kingdom, Japan, Italy, France, the Netherlands, Belgium, Sweden, Denmark, Spain, Portugal, Peru and Brazil ${ }^{34}$. These treaties had an extraterritorial object ${ }^{35}$. The well-known treaty of Nanking imposed by the United Kingdom on the 29th August 1842 is one of these ${ }^{36}$. By the application of the extraterritoriality principle, the nationals of one State cannot be submitted to the jurisdiction of the foreign State in which he is, or in which he has established business. In China, for example, foreigners under this regime were not under the empire of Chinese law but under the jurisdiction of their own national law ${ }^{37}$. This extraterritoriality was obviously not reciprocal; Chinese citizens did not have this privilege abroad. An author described and justified this unequal relationship as such - and the quote, although extensive, is telling and informative:

The very necessity of things requires ... that certain States should not be called to enjoy international rights in an integral fashion as with perfect equality. So it is reasonable that the States of Europe should not admit perfect equality with Turkey and its dependencies; with the States of Africa, with the exception of Liberia and the English and French colonies; with the States of Asia, with the exception of Siberia and Hindostan. .. . we may lay down the following rules:

unequal treaties doctrine. Boston College of International and Comparative Law Review, v. 2, n. 2, p. 455-460, 1979; GREENBERG, Katherine.A. Hong Kong's future: Can the People's Republic of China Invalidade the Treaty of Nanking As an Unequal Treaty? Fordham International Law Journal, v. 7, p. 544-548, 1984; KU, Charlotte. Abolition of China's unequal treaties and the search for regional stability in Asia, 1919-1943. Chinese/Taiwan Yearbook of International Law and Affairs, v. 12, p. 67-86, 1992-1994; NOZARI, Fariborz. Unequal Treaties in International Law. Stockholm: S-Bryan Sundt, 1971. p.201.

\section{PETERS, op. cit., p. 3.}

34 WANG, op. cit., p. 241; WOOLSEY, L.H. [intervention]. The Termination of unequal treaties. American Society of International Law Proceedings, v. 21, p. 96, 1927.

35 CRAVEN, op. cit., p. 34; DETTER, op. cit., p. 1075; SCOTT, Shirley V. The Problem of unequal treaties in contemporary international law: how the powerful have reneged on the political compacts within which five cornerstone treaties of global governance are situated. Journal of International Law and International Relations, v. 4, n. 2, p.105, 2008.

36 WANG, op. cit., p. 237. See pages 252-253 for a list of matters present in Chines Treaties.

37 NOZARI, op. cit., p. 159; PETERS, op. cit., p. 4. 
(a) Full and entire juridical equality ought to be limited to those States among which there have been developed the fundamental juridical ideas essential to the co-existence of States in society.

(b) A State which does not find itself in a position to fulfil its international duties towards other States, either as a result of traditional prejudices, of its internal organization, or its customs and its religious beliefs, can only demand the full enjoyment of international rights in perfect equality on condition that it change its internal organization so as to enable it to fulfil its international duties by giving substantial guarantees on this subject...

(c) As long as such reforms are not carried out within those States, other States which have relations with them ought to observe the stipulations of treaties. ${ }^{38}$

The theory of unequal treaties has not always been recognised by the majority of the doctrine in international law, especially the European one ${ }^{39}$. Contextually, this is normal. The European States were the 'superior' and dominant parties to these agreements and the European doctrine of this epoch and even of more recent times considered this legal configuration as something obeying to the utmost normality. And utmost normality is never questioned. Logically, in the opposite sense, the doctrinal approach of States suffering from these treaties was different and they were qualified as unequal and humiliating ${ }^{40}$. It is in great part the Chinese and Russian authors who have forged the theory of unequal treaties $^{41}$. For the Russian doctrine, the majority of treaties emanating from States following a capitalist and market-based economy was unequal especially when concluded with developing States. They were means to enslave powerless States ${ }^{42}$. Hence, treaties having for principal object military bases on foreign territories or those concerning economical and technical assistance between States, those providing for credits and loans were

38 FIORE, Pasquale. Diritto internazionale. Torino: 1904. p. 291, quoted by: DETTER, op. cit., p. 1076.

39 DAILLIER, Patrick; PELLET, Alain. Droit International Public. 7. ed. Paris: L.G.D.J., 2002, p. 201; PETERS, op. cit., p. 7; WANG, op. cit. p. 335.

40 WANG, op. cit., p. 334-335; PETERS, op. cit., p. 7.

41 PETERS, op. cit., p. 7.

42 KRYLOV, Serge. La notion principale du droit des gens: la doctrine soviétique du droit international. R.C.A.D.I., ano 1, v. 70 , p. 434, 1947. considered as unequal and void ${ }^{43}$. For this doctrine, the unique imbalance of power of the signatories invalidates the agreement. The inequality of the parties colours the agreements they sign and this kills their legal value and existence $^{44}$. This was also the position of many newly decolonised States ${ }^{45}$. The African-Asian Conference, having met for the first time in Bandung in 1955 voted a resolution on unequal treaties in 1957 defining them, therein, as openly imbalanced treaties imposed by the powerful States on the powerless ones ${ }^{47}$. One draft constitution of the Popular Republic of China affirmed the will of the Chinese people to denounce, renegotiate or revise the treaties signed by the Empire so as to abolish all the privileges of the foreign powers ${ }^{48}$. China, in fact, undertook various initiatives to denounce these treaties ${ }^{49}$. From the stance of those who bore these agreements, domination and humiliation were the leitmotifs. There are various other reasons explaining unequal treaties.

\section{(B) The reasons behind unequal treaties.}

Two main series of reasons ground the logic of unequal treaties. The first one has a civilisational character, the second, an economical one. Firstly, the civilisational reason is related to the difference in the legal culture and in the general culture of States. In this sense, the Chinese law was not of immediate access and understanding to Europeans because of the language barrier and also because the principles, rules and customs differed utterly ${ }^{50}$. In Imperial China,

43 LUKASHUK, I. The Soviet Union and international treaties. Soviet Yearbook of International Law, 1959, p.16-50; TALALEV, A; BOYARSHINOV, V.G. Unequal Treaties as a Mode of Prolonging the Colonial Dependence of the New States of Asia and Africa. Soviet Yearbook of International Law, p. 156-170, 1961. These texts being in Russian, the arguments made by their authors have been taken from: PETERS, op. cit, p. 7. See also: DETTER, Ingrid. The Problem of Unequal Treaties. International and Comparative Law Quarterly, v. 15, p. 1082, 1966.

44 FINKELSTEIN, Jesse. A. An examination of the treaties governing the far-eastern sino-soviet border in light of the unequal treaties doctrine. Boston College of International and Comparative Law Review, v. 2, n. 2, p. 452-461, 1979.

45 SINHA, Prakash. Perspective of the Newly Independent States on the Binding Quality of International Law. International and Comparative Law Quarterly, v. 14, p. 124, 1965.

46 For a summary of the conference, see: VARELLA, Marcelo Dias. Direito internacional econômico ambiental. Belo Horizonte: Del Rey, 2003. p. $10-11$.

47 WANG, op. cit., p. 336.

48 WANG, op. cit., p. 337.

49 WANG, op. cit., p.260.

50 DETTER, op. cit., p. 1078. 
law had a relative value and there was a reign of a Confucian conception of the social structure whereby non-legal rules of behaviour which the citizens imposed to themselves to regulate their social life were more important and were therefore given priority over the sovereign rules. The legal culture as it existed in Europe at that time was inexistent in China ${ }^{51}$. The principle of the separation of powers, dear to many European States, did not have roots in $\mathrm{China}^{52}$. In another region, the Ottoman Empire had also signed capitulation treaties with Western European States or with the United States. The inequality here was not, as a matter of fact, related to the element of power, the Empire being itself a dominant one under the rule of the sultans. The Empire's territory was under the jurisdiction of islamic law which did not apply to nonmuslims. As a result, treaties passed with the sultans enabled non-muslim foreigners to remain under the jurisdiction of their State of nationality on the Empire's territory; here, there was not a real subordination ${ }^{53}$. These were some factors which justified, initially, the will to establish such conventional relationship qualified as unequal. However, and this is the second reason, a mercantile objective also lurked behind these treaties. The United States, for example, wanted to maintain its extraterritorial rights on the Moroccan soil at any cost even when the latter State fell under the French protectorate regime, and therefore under French law ${ }^{54}$. The same trade-oriented will applied in the Chinese case. The interests of the independent States of that era in building and maintaining a relationship with China were, of course, commercial ones. The aim of the treaties they imposed was to open the Chinese market and to exploit the Chinese production. It is this political and economical conjunction which lead China - unfavourable to any foreign presence on its territory -, to the two Opium wars in 1839 and 1857 respectively. These wars resulted in the above-mentioned Treaty of Nanking with the United Kingdom in 1842 and in that of Tientsin with the United Kingdom, France and

51 LEGEAIS, Raymond. Grands systèmes de droit contemporains: approche comparative. Paris: Litec, 2008. p. 218-224.

52 DETTTER, op. cit., p. 1078.

53 DETTER, op. cit. p. 1077; NOLDE, Boris. Droits et techniques des traités de commerce. R.C.A.D.I., ano 2, v. 3, p. 304; NOZARI, Fariborz. Unequal treaties in international law. Stockholm: S-Bryan Sundt, 1971. p. 161-162; STRISOWER, Leo. L'extraterritorialité et ses principales applications. R.C.A.D.I., ano 1, v. 1 , p. $234,1923$.

54 DETTER, op. cit., p.1081. the United-States in $1858^{55}$. The first one provided for an extraterritorial regime for British citizens in China whilst the second legalised the trade of of opium with special tariffs. It is namely after the conclusion of these treaties that China suffered from the imposition of other unequal treaties by other States ${ }^{56}$. The effects of these treaties were worsened by the existence in their provisions of a most-favoured nation clause. The advantage or privilege offered to a State had to be extended to the others ${ }^{57}$ and this deepened the disequilibrium of the relations with China.

This being said, modern international law does not, as such, prohibit these types of treaties containing rights and duties with no or with relative reciprocity ${ }^{58}$. According to Judge Simma, reciprocity is the status of a relationship between two or more States whereby the behaviour of one party is in one way or the other legally dependent on the other party's posture ${ }^{59}$. It constitutes, nowadays, the pillar of a conventional relationship and contrarily to most ancient treaties ${ }^{60}$, it does not have to be mentioned and highlighted in the agreements' body. Reciprocity is normality: it is the principle. The rights and obligations of the parties have a reflective effect even if the mirror can have a deformity, thereby attributing more rights or obligations to one party or to the other. As per the Vienna Convention on the Law of Treaties (1969), a treaty is void only if it has been concluded by the use of force or by threat ${ }^{61}$, by error, by fraud ${ }^{62}$, by corruption ${ }^{63}$ or coercion of the State's representative ${ }^{64}$. An imbalanced treaty between sovereign States is not void and invalid if it has been concluded in conformity with the Vienna Convention. This however does not mean that a disequilibrium

55 NOZARI, op. cit., p. 201-211; WANG, op. cit., p. 237-253.

56 NOZARI, op. cit., p. 201-202.

57 CRAVEN, op. cit., p. 343-344; PETERS, op. cit., p.4.

58 PAULUS, Andreas. Reciprocity revisited. In: FASTENRATH et al. From Bilateralism to Community Interest: essays in honour of Judge Bruno Simma. Oxford: Oxford University Press, 2011. p. 119; SIMMA, Buno. Recriprocity: the max planck encyclopedia of public international law. Oxford University Press, 2008. Available on: <www.mpepil.com> p. 4 .

59 SIMMA, op. cit., p. 2.

60 See: NOLDE Boris. Droits et techniques des traités de commerce. R.C.A.D.I., ano 2, v. 3, p. 320-321, 1924.

61 See article 52 of the Vienna Convention on the Law of Treaties, available on: http://untreaty.un.org/ilc/texts/instruments/ francais/traites/1_1_1969_francais.pdf

62 See article 49 of the Vienna Convention on the Law of Treaties.

63 See article 50 of the Vienna Convention on the Law of Treaties.

64 See article 51 of the Vienna Convention on the Law of Treaties. 
characterising an agreement does not give rise to any practical problem. The latter can be of a political character but it obeys to a legal concretisation in the case of a treaty denunciation, for example, - and it is not useless to pay attention to the reasons underscoring treaty denunciation. The denunciation of bilateral investment treaties by Venezuela or by Ecuador and the will of some States, often developing ones, to end the investment-related agreements by which they are linked is justified by the disequilibrium inherent to their conventional relationship with industrialised States $^{65}$. If these agreements are legally founded and valid, they have become unacceptable for some. The aim here is not to affirm that bilateral investment treaties are by definition always unequal and that this is condemnable or must be condemned, but to understand what legal consequences are attached to an eventual disequilibrium.

\section{Upholding the Relativity of Bilateral Investment} Treaties as Unequal Treaties

Understanding the overall equilibrium of bilateral investment treaties (A) enables to affirm that they do not pertain to the category of unequal treaties when studied through the lenses of the unequal treaties theory (B).

A) Understanding The Overall Equilibrium of Bilateral Investment Treaties

Firstly, the procedural equilibrium of the bilateral treaties has to be examined (i); secondly, the study has to focus on the material provisions of these treaties in order to see if they unreasonably favour one party more than the other and if, in so doing, the latter finds itself in a position of subordination, forcefully at the mercy of his economic partner (ii).

65 FACH, op. cit., p. 216-221; MACHADO, Decio. Ecuador y la denuncia de los Tratados Bilaterales de Inversión. CATDM, 7 dec. 2009. Available at: $<$ http://www.cadtm.org/Ecuador-y-la-denunciade-los>; VAN, Harten Gus. Five Justifications for Investment Treaties: A Critical Discussion. Trade, Law and Development, v. 2, n. 1, 2010. Available at: <http://www.tradelawdevelopment.com/index. $\mathrm{php} / \mathrm{tld} /$ article/view/2(1)\%20TL\%26D\%2019\%20(2010)/38>; VIS-DUNBAR, Damon. Analysis: Latin America's new model bilateral investment treaties. Investment Treaty News, 17 jul. 2008. Available on: <http://www.iisd.org/itn/2008/07/17/in-depthlatin-america-s-new-model-bilateral-investment-treaties $/>$. (i) The question of the procedural inequality of bilateral investment treaties.

On a procedural level, the existence of a disequilibrium is often decried in that the investors are always the claimants before arbitral tribunals and that the States are always the defendants even if the arbitration rules enables them to produce counterclaims $^{66}$. There is no reciprocity in the capacity of asking for the constitution of an arbitral tribunal ${ }^{67}$. The investor finds himself in a monopoly position enabling him to trigger the arbitral procedure following his will ${ }^{68}$. Consequently, a State cannot sue an investor in international investment arbitration. This situation had already been noticed before the Iran-US claims tribunal in a case of the 21st December 1981 concerning the tribunal's competence following Iran's claims against nationals of the United-States ${ }^{69}$. On the basis of the Algiers declarations, Iran asked the tribunal to declare its competence to receive its claims against American companies. According to article II of the Declaration on the settlement of claims, the tribunal is competent for cases implying the claims of American citizens against Iran or for the claims of Iranian citizens agains the United-States. At the same time, the tribunal is competent for any contractual dispute between Iran and the United-States ${ }^{70}$. Iran argued that it was founded

66 See : article 46 of The Washington Convention instituting ICSID and article 40 of the Arbitration Rules; WALDE Thomas. Procedural Challenge in Investment Arbitration Under the Shadow of the Dual role of States. Asymmetries and Tribunals' Duty to Encure Pro-Actively, the Equality of Arms. Arbitration International, vol.26, no.1, 2010, pp.15-16.

67 BEN, Hamida Walid. Le système actuel est-il déséquilibré en faveur de l'investisseur privé étranger et au détriment de l'Etat d'accueil? (Table Ronde). In: LEBEN, Charles (Org.). Le contentieux arbitral transnational relatif à l'investissement. Nouveaux Développements. Paris: L.G.D.J., 2006. p.200.

68 SORNARAJAH, Muthucumaraswamy. Power and Justice: Third World Resistence in International Law. Singapore Yearbook of International Law, v. 10, p. 32, 2006.

69 Case related to the tribunal's competence following Iranian claims against American citizens, award, 21 December 1981 (signed on the 13th January 1982), Iran-US Claims Tribunal, International Legal Materials, vol.21, 1982, pp.78-91. For a commentary of the award, see, voir: STERN (B.), A propos d'une sentence d'un Tribunal des différends irano-américain, Annuaire française de droit international, v. 28, p. 425-453, 1982.

70 Case related to the tribunal's competence following Iranian claims against American citizens, award, 21 December 1981 (signed on the 13th January 1982), Iran-US Claims Tribunal, International Legal Materials, v. 21, p. 80, 1982. 
to submit a claim against American companies. The tribunal rejected the claim and explained that if Iran could submit a counterclaim against American citizens - which supposed that the latter had already started legal proceedings -, no interpretation could imply that the parties had initially provided for the triggering of the procedure by a State against a national ${ }^{71}$. Hence, in the relationship between private person and State, the initiative of action rested in the former's hands. This award was rendered with three dissenting opinions. The dissenting arbitrators underlined the absence of consideration of the reciprocity principle by the tribunal. They affirmed that the Algiers Declarations were built on this principle which is the ratio of mutual obligations between the States ${ }^{72}$. In their opinion, the Declarations must not be interpreted in a way to benefit only one of the parties so that the other's claims be forever classified as procedurally inadmissible because if this was the case, the Declarations would lose their equilibrium and would be wither without a cause or with a superficial cause. The reasons on which they rest to support this position is contextual; the context is such that there is a higher probability that it is an American company which starts proceedings against Iran than an Iranian company against the UnitedStates. The tribunal, say the dissenting arbitrators, has not considered this context and this deprives the provision providing for Iranian claims against the United-States of any effectivity and leaves it with a mere poetical effect, they $\operatorname{add}^{73}$. In this situation where only American companies have the upper hand, these arbitrators do not understand why Iran has to bear half of the tribunal's expenses. As for counterclaims, they argue that these are means of defence which can be used against a claimant for an action which has already started and that in any case, producing a counterclaim

71 Case related to the tribunal's competence following Iranian claims against American citizens, award, 21 December 1981 (signed on the 13th January 1982), Iran-US Claims Tribunal, International Legal Materials, v. 21, p. 81-82, 1982.

72 Case related to the tribunal's competence following Iranian claims against American citizens, award, 21 December 1981 (signed on the 13th January 1982), Iran-US Claims Tribunal, International Legal Materials, v. 21, p. 85, 1982.

73 Case related to the tribunal's competence following Iranian claims against American citizens, award, 21 December 1981 (signed on the 13th January 1982), Iran-US Claims Tribunal, Dissenting Opinion of arbitrators Kashani, Shafieie et Hossein Enayat,International Legal Materials, v. 21, p. 87, 1982. is a right which is made available to any defendant ${ }^{74}$. Conceptually, the point on which they dissented was the absence of equilibrium between the parties which is prone to kill the reciprocity of any agreement. It is exactly on this background that investor-State arbitration is held in international investment law. Investors and States have pre-defined and preestablished roles.

According to an author, this is normal as the private investor is himself in an unequal position, taken as a hostage, he claims, by the double function of the State which is on one hand, a contracting party and on the other, the public person with regulatory powers, with prérogatives de puissance publique ${ }^{75}$. There is perhaps an exaggerated reference to a hostage-like situation, especially when many multinational companies are sometimes more powerful than their State partners ${ }^{76}$. The author however adopts an interesting analogical approach. He compares the logic of international investment arbitration to administrative law or to other international legal procedure, like the one applicable before the European Court of Human Rights, whereby only the person having suffered a damage has the capacity to start a proceeding against a State which has promised to abide to certain obligations; any asymmetry is consequently implicit but at the same time, quite normal ${ }^{77}$ - and surely accepted. If it is an arbitration to assess the responsibility of the host State of an investor, the procedure is very close to a control of legality found in administrative law, especially the French one, and in this case, it is obvious that only one party can start the arbitration machinery ${ }^{78}$. The difference with

74 Case related to the tribunal's competence following Iranian claims against American citizens, award, 21 December 1981 (signed on the 13th January 1982), Iran-US Claims Tribunal, Dissenting Opinion of arbitrators Kashani, Shafieie et Hossein Enayat,International Legal Materials, v. 21, p. 88, 1982.

75 WALDE, op.cit., p. 15-16.

76 See, MAUREL Olivier. La responsabilité des entreprises en matière de droits de l'homme. I. Nouveaux enjeux, nouveaux Rôles. Étude de la Commission Nationale Consultative des Droits de l'Homme, Paris: La Documentation Française, 2009, pp.263-264: The study establishes the ranking of the 100 richest States and multinational companies and it shows that the revenu of these companies is superior to the gross national product of many States; SORNARAJAH Muthucumaraswamy. The Settlement of Foreign Investment Disputes. The Hague: Kluwer Law International, 2000, p.14.

77 WALDE, op. cit., p. 15-16.

78 BURDEAU, Geneviève. Le système actuel est-il déséquilibré en faveur de l'investisseur privé étranger et au détriment de l'Etat d'accueil? (Table Ronde). In: LEBEN, op. cit., p. 187. 
administrative law is that in investment arbitration, the claimant is always a foreign company. What is surely somehow disturbing for some and what eventually takes the form or the appearance of a disequilibrium is the image of the multinational company which ferociously distrusts the national tribunals of the host State and which prefers the jurisdiction of international arbitral tribunals. This situation of a dominant foreigner with such power against a State, especially when the latter is a developing one, gives birth to the mental image of the colonial usurper having a violent force of domination and enslavement on State's sovereignty. Finally, it may be that the disequilibrium is only a question of image or of images' association. Indeed, it is less disturbing and less questionable when a private person or company sues the State of which he is a national before an administrative tribunal of the municipal legal order. The same can be said as far as the European Court of Human Rights or the Inter-American Court of Human Rights are concerned. For these reasons, assimilating bilateral investment treaties with unequal treaties can be tricky considering, moreover, that these treaties are not imposed by violence and are done in crystal-clear legality, in conformity with the Vienna Convention on the Law of Treaties ${ }^{79}$. It is mostly the extraneous character of the private foreign investor which gives rise to the question of inequality which must now be assessed following the substantial provisions of bilateral investment treaties.

(ii) The Question of the Substantial Inequality of Bilateral Investment Treaties

These treaties are often criticised because of the numerous and important rights they confer to investors without providing for equivalent obligations ${ }^{80}$. Reading any bilateral investment treaty confirms the large extent of protection granted to investors, sometimes even overprotected by the application of the mostfavoured nation clause. It is very rare to see bilateral investment treaties containing any substantial provision

79 See article 52 of the Vienna Convention on the Law of Treaties, available on: http://untreaty.un.org/ilc/texts/instruments/ francais/traites/1_1_1969_francais.pdf

80 JUILLARD, op. cit., p. 190-191.; MUCHLINSKI, Peter. Corporate Social Responsibility. In: MUCHLINSKI Peter. et al. The Oxford Handbook of International Investment Law. Oxford: Oxford University Press, 2008. p. 638; SORNARAJAH, Muthucumaraswamy. Power and Justice: Third World Resistence in International Law. Singapore Yearbook of International Law, v. 10, p. 32, 2006. on development objectives or other State interest for example. As aforementioned, this is due to an inequality in the bargaining and negotiating power of States $^{81}$. This being said, the situation is a formalisation of a legal bilateralism as it is possible to clearly identify who has rights and obligations and by whom these can be enforced ${ }^{82}$. However, the effectivity of norms in bilateral agreements is guaranteed by the principle of reciprocity ${ }^{83}$, and it is in this sense that bilateral investment treaties are sometimes considered as practically unilateral. The relationship between private persons and States makes sense only if these actors accept and recognise each other mutually and if, at the same time, they acknowledge their respective interests. This is what must be understood by reciprocity which, as put by Professor Virally, is the soul of treaties ${ }^{84}$; outside this framework, the relationship is that of a master and a slave or that of a permanent state of war, he $\operatorname{argues}^{85}$. Bilateral treaties are not unilateral acts providing privileges to foreign traders against any form of violence as it was the case in Europe between the VIIIe and the XIIIe century ${ }^{86}$. This unilateral aspect of investment treaties must, nonetheless, be processed through relativity.

The legal reciprocity of a bilateral investment treaty in fact means that the investors from both signatory States can invoke the treaties' provisions against a reprehensible behaviour of the host State. On the basis of a bilateral investment treaty between the United Kingdom and Russia, a British investor can sue the Russian State if the latter infringes the treaty's provisions and similarly, a Russian investor vexed by the United Kingdom can ask for the constitution of an arbitral tribunal to seek damages. Both investors are protected in a similar fashion. Legally, the principle of reciprocity is not frustrated; it concerns the reciprocal actions of private investors from the States parties to the treaty rather than the States' actions themselves. Again, some bitter relativity must be brought here, and this is related to the status of the States having signed the agreement. In his Hague lecture, Professor

81 VIRALLY, Michel. Le principe de réciprocité dans le droit international contemporain. R.C.A.D.I., ano 3, v. 122, p. 66, 1967.

82 SIMMA, Bruno. From Bilateral to Community Interest in International Law. R.C.A.D.I., ano 4, v. 250, p. 232-233, 1994.

83 Ibid, p. 233.

84 VIRALLY, op. cit., p.6.

85 Ibid. p. 5.

86 See: NOLDE, op. cit., p. 299-305. 
Virally raised the question of the possibility of any reciprocity when one of the partners was a developing State ${ }^{87}$. The legal equality is not a factual equality. To continue with the same example, the United Kingdom is also a party to bilateral investment treaties signed with States like Haiti, Nepal, Burundi or Cameroon. The question here is of a practical and logical order. There are certainly more British investors in Nepal or Cameroon than Nepalese or Cameroonese investors in the United Kingdom. Thus, it is more probable that the treaty be really useful only to British investors. The economic disparity between the States frames the treaty to the only benefit and use of the investor from developed States as he only has sufficient means to undertake international investments. What has been said is far from being subversive and demagogical but is a mere description of reality. Despite the rise of the so-called BRICS, there are, for the time being, more investments circulation from developed States towards developing ones ${ }^{88}$. On these grounds, the bilateralism can be doubtful. Reciprocity exists in law and this cannot be denied. It however sometimes remains in its theoretical aspect and loses itself behind a factual inequality. But, in any case, any disequilibrium which might characterise investment treaties is, in reality, an accepted disequilibrium.

\section{B) Affirming The Voluntary Disequilibrium Of} Bilateral Investment Treaty.

From the precedent analysis, it is possible to conclude that bilateral investment treaties are theoretically equal but that some relativity must sometimes be injected, especially when it comes to the interaction between developing and developed States. Nevertheless, these agreements are not forcefully imposed on States as it was in the case of Imperial China. There is an obvious difference in the economic level and negotiation capacity of the States but bilateral investment treaties are always signed voluntarily ${ }^{89}$; even those States which denounce such treaties later on had initially consented as per the requirements of the Vienna Convention on the Law of Treaties. It is true that some States did not master the appropriate technical tools of international investment law and have signed such agreements without an iota

87 VIRALLY, op. cit., p. 88-89.

88 JUILLARD, Patrick. L'évolution des sources du droit des investissements. R.C.A.D.I., ano 4, v. 250, p. 107, 1994.

89 BEN, op. cit., p. 201. of knowledge of the future consequences. As Professor Juillard ironically stated, very often, the treaty models of developed States were just sent to the relevant ministry of developing States and a few days later, the treaties were sent back with the competent authority's signature $^{90}$. Other States engage in such agreements even if they are aware that their citizens will probably not invest abroad simply because they expect to derive some benefits in terms of an increase in the level of foreign investments or in terms of a consolidation of the political relationship with the other partner ${ }^{91}$. It is a sort of compromise of interests which do not, as such, pertain to the field of law. The United Nations Charter, for historical reasons, provides for the existence of five permanent members with a right of veto ${ }^{92}$. If this is a form of inequality between States, many States accept it despite the gradual evaporation of the historical reasons. The question is not whether there is or not a voluntary servitude from some States; legally speaking, the signature and the ratification means consent and therefore, the State has to abide to its conventional engagement in good faith ${ }^{93}$ whether it is based on an equal or an unequal foundation, and whether it is or not reciprocal. The consequences have to be measured before the signature. The latter, once sealed, is submitted to pacta sund servanda ${ }^{94}$. If some States are no longer satisfied with such agreements, they have the possibility of denouncing them ${ }^{95}$ or of refusing their extension. This is an attribute of their sovereignty. They cannot be engaged without their will ${ }^{96}$, but once the consent has been given, it remains legally valid and binding.

90 JUILLARD, Patrick. Le système actuel est-il déséquilibré en faveur de l'investisseur privé étranger et au détriment de l'Etat d'accueil? (Table Ronde). In: LEBEN, Charles. (Org.). Le contentieux arbitral transnational relatif à l'investissement. op. cit., p.191.

91 PAULUS, op. cit., p.117.

92 See United Nations Charter, article 23, article 27, Available on: <http://www.un.org/fr/documents/charter/>

93 See article 26 of the Vienna Convention on the Law of Treaties.

94 See article 26 of the Vienna Convention on the Law of Treaties; see also: Nuclear Tests (Australia v. France), Judgement, 20 December 1974, I.C.J., ICJ Reports, 1974, p. 268, \$46.

95 See article 56 of the Vienna Convention on the Law of Treaties.

96 Case of the S.S. Lotus (France c. Turkey), judgement, 7th September 1927, Permanent court of International Justice, Series A., n. 10, p.18. 


\section{Bibliography}

ALEXANDER, Emily. A. Taking account of reality: adopting contextual standards for developing countries in International Investment Law. Virginia Journal of International Law, v. 48, p. 817-841, 2008.

CRAVEN, Matthew. What Happened to Unequal Treaties? the continuities of informal empire. Nordic Journal of International Law, v. 74, p.335-382, 2005.

DAILLIER, Patrick; PELLET Alain. Droit International Public. 7. ed. Paris: L.G.D.J, 2002.

DETTER, Ingrid. The problem of unequal treaties. International and Comparative Law Quarterly, v. 15, p. 10691089, 1966.

EL BOUDOUHI, Saïda. L'intérêt général et les règles substantielles de protection des investissements. AFDI, p. $542-563,2005$.

FACH, Katia Gomez. Latin America and ICSID: David versus Goliath. Law and Business Review of the Americas, v. 17, p. 195-230, 2011.

FINKELSTEIN, Jesse. A. An examination of the treaties governing the Far-Eastern Sino-Soviet Border in light of the unequal treaties doctrine. Boston College of International and Comparative Law Review, v. 2, n. 2, p. 452-461, 1979.

FRANCK, Suzanne. Development and Outcome of Investment Treaty Arbitration. Harvard International Law Journal, v. 50, n. 2, p. 435-489, 2009.

GAILLARD, Emmanuel. Anti-Arbitration Trends in Latin America. New York Law Journal, v. 239, n. 108, 2008.

GARCIA-BOLIVAR, OmarE. The surge of investment disputes: Latin America testing the international law of foreign investments. In: GENERAL CONFERENCE OF THE ASIAN SOCIETY OF INTERNATIONAL LAW, 2., 2009, Tokyo. Proceedings...Tokyo 2009.

GIDEL, Guillaume. Droits et devoirs des nations: la théorie classique des droits fondamentaux des Etats. R.C.A.D.I., ano 2, v. 10, p. 537-597, 1925.

GREENBERG, Katherine. A. Hong Kong's future: Can the People's Republic of China Invalidade the Treaty of Nanking As an Unequal Treaty? Fordham International Law Journal, v. 7, p. 534-560, 1984.
GROTIUS, Hugo. Le droit de la guerre et de la paix. Trad. Jean Barbeyrac. Amsterdam: Pierre de Coup, 1724. t. 2. cap. 15.

HELLIO, Hugues. L' Etat, un justiciable de second ordre? A propos des demandes étatiques dans le contentieux arbitral transnational relatif aux investissements étrangers. RGDIP, v. 113, n. 3, p. 589-620, 2009.

JUILLARD, Patrick. L'évolution des sources du droit des investissements. R.C.A.D.I., ano 6, v. 250, p. 9-216, 1994.

KRYLOV, Serge. La notion principale du droit des gens: la doctrine soviétique du droit international. R.C.A.D.I., ano 1, v. 70, p. 407-476, 1947.

KELSEN, Hans. Théorie générale du droit international public: problèmes choisis. R.C.A.D.I., ano 4, v. 42, p. 117-352, 1932.

$\mathrm{KU}$, Charlotte. Abolition of China's unequal treaties and the search for regional stability in Asia, 1919-1943. Chinese/Taiwan Yearbook of International Law and Affairs, v. 12, p. 67-86, 1992-1994.

LEGEAIS, Raymond. Grands systèmes de droit contemporains: approche comparative. Paris: Litec, 2008.

MACHADO, Decio. Ecuador y la denuncia de los Tratados Bilaterales de Inversión. CATDM, 7 dec. 2009. Available at: <http://www.cadtm.org/Ecuadory-la-denuncia-de-los $>$.

MALIK, Manaz. South-South Bilateral Investment Treaties: the same old story? In: FORUM FOR DEVELOPING COUNTRY INVESTMENT NEGOTIATORS BACKGROUND PAPERS NEW DELHI, 4., 2010. Anais... 2010. In: THE INTERNATIONALINSTITUTEOFSUSTAINABLE DEVELOPMENT, 2011, p.1-5. Available on: <http:// www.iisd.org/pdf/2011/dci_2010_south_bits.pdf>.

MAUREL, Olivier. La responsabilité des entreprises en matière de droits de l'homme: nouveaux enjeux, nouveaux rôles: étude de la Commission Nationale Consultative des Droits de l'Homme: Paris: la documentation Française, 2009.

MUCHLINSKI, Peter. Corporate social responsibility. In: MUCHLINSKI, Peter et al. The Oxford Handbook of International Investment Law. Oxford: Oxford University Press, 2008. 
MCNAIR, Arnold D. Equality in international law. Michigan Law Review, v. 26, n. 2, p. 131-152, déc. 1927.

NOZARI, Fariborz. Unequal treaties in international law. Stockholm: S-Bryan Sundt, 1971.

OPPENHEIM, Lassa. International Law: a treaties. 3. ed. Londres: Ronald F. Roxburg, 2008. v. 1.

PAULUS, Andreas. Reciprocity revisited. In: FASTENRATH et al. From bilateralism to community interest: essays in honour of Judge Bruno Simma. Oxford: Oxford University Press, 2011.

PETERS, Anne. Unequal treaties: the max planck encyclopedia of public international law. Oxford University Press, 2011. Available on: <www.mpepil.com>.

PREUSS, Ulrich K. Equality of States-Its meaning in a constitutionalized global order. Chicago Journal of International Law, v. 9, p. 17-50, 2008-2009.

SCHINDLER, Dietrich. Contribution à l'étude des facteurs sociologiques et psychologiques du droit international. R.C.A.D.I., ano 4, v. 46, p. 229-326, 1928.

SCOTT, James Brown. Le principe de l'égalité juridique dans les rapports internationaux. R.C.A.D.I., ano 4, v. 42, p. 467-360, 1932.

SCOTT, Shirley V. The problem of unequal treaties in contemporary international law: how the powerful have reneged on the political compacts within which five cornerstone treaties of global governance are situated. Journal of International Law and International Relations, v. 4, n. 2, p. 101-126, 2008.

SIMMA, Buno. Recriprocity: the max planck encyclopedia of public international law. Oxford University Press, 2008. Available on: <www.mpepil.com>.

SIMMA, Bruno. From bilateral to community interest in international law. R.C.A.D.I., ano 6, v. 250, p. 217-384, 1994.

SINHA, S. Prakash. Perspective of the Newly Independent States on the Binding Quality of International Law. International and Comparative Law Quarterly, v. 14, p. 121-131, 1965.

SORNARAJAH, Muthucumaraswamy. The Settlement of Foreign Investment Disputes. The Hague: Kluwer Law International, 2000.
SORNARAJAH, Muthucumaraswamy. Power and Justice: Third World Resistence in International Law. Singapore Yearbook of International Law, v. 10, p. 19-57, 2006.

STRISOWER, Leo. L'extraterritorialité et ses principales applications. R.C.A.D.I., ano 1, v. 1, p. 229-288, 1923.

VANDEVELDE, Kenneth.J.A briefhistory of international investment agreements. University of California Davis Journal of International Law and Policy, v. 12, p. 157-194, 2005.

VAN, Gus Harten. Five Justifications for Investment Treaties: a critical discussion. Trade, Law and Development, v. 2, n. 1, 2010. Available at: <http://www. tradelawdevelopment.com/index.php/tld/article/ view/2(1)\%20TL $\% 26 \mathrm{D} \% 2019 \% 20(2010) / 38)>$.

VAN, Thomas Ann Wynen; THOMAS JUNIOR, A.J. Equality of States in International Law: fact or fiction? Virginia Law Review, v. 37, n. 6, p. 801-802, oct. 1951.

VARELLA Marcelo Dias. Direito internacional econômico ambiental. Belo Horizonte: Del Rey, 2003.

VERDROSS, Alfred. Règles générales du droit international de la paix. R.C.A.D.I., ano 5, v. 30, p. 271 518, 1929.

VIRALLY, Michel. Le principe de réciprocité dans le droit international contemporain. R.C.A.D.I., ano 3, v. 122, p.1-106, 1967.

VIS-DUNBAR, Damon. Analysis: Latin America's new model bilateral investment treaties. Investment Treaty News, 17 jul. 2008. Available at: <http://www.iisd.org/ itn/2008/07/17/in-depth-latin-america-s-new-modelbilateral-investment-treaties/ $>$.

WALDE, Thomas. Procedural challenge in investment arbitration under the shadow of the dual role of States: asymmetries and Tribunals' Duty to Encure ProActively, the Equality of Arms. Arbitration International, v. 26, n. 1, p. 3-42, 2010.

WANG, Tieya. International law in China: historical and contemporary perspectives. R.C.A.D.I., ano 2, v. 221, p. 195-370, 1990.

WHITSITT, Elizabeth; VIS-DUNBAR, Damon. Investment arbitration in Brazil: yes or no? Investment Treaty News, 30 nov. 2008. Available on: <http://www. iisd.org/itn/2008/11/30/investment-arbitration-inbrazil-yes-or-no/>. 
Para publicar na Revista de Direito Internacional, acesse o endereço eletrônico www.rdi.uniceub.br ou www.brazilianjournal.org.

Observe as normas de publicação, para facilitar e agilizar o trabalho de edição. 